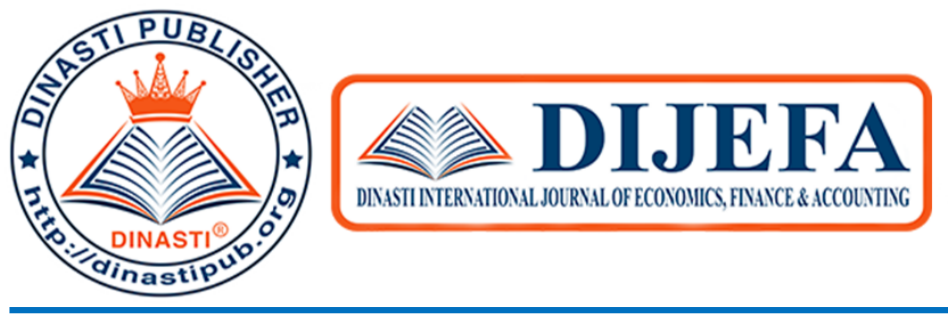

+6281387654578@

+6281387654578 @

https://dinastipub.org/DIJEFA (7)

dinasti-info@gmail.com ๑.

\title{
DETERMINANT OF CAPITAL STRUCTURE OF PROPERTY \& REAL ESTATE COMPANIES IN INDONESIA STOCK EXCHANGE
}

\author{
Muhammad Surya Alam ${ }^{1)}$, Augustina Kurniasih' ${ }^{2)}$ \\ Universitas Mercu Buana, Jakarta, Indonesia
}

\begin{tabular}{|c|l|}
\hline $\begin{array}{c}\text { ARTICLE INFORMATION } \\
\text { Received: 18 August 2020 } \\
\text { Revised: 30 August 2020 } \\
\text { Issued: 24 September 2020 }\end{array}$ & $\begin{array}{l}\text { Abstract: This study aims to analyze the factors } \\
\text { that influence the capital structure of property \& } \\
\text { real estate companies contained on the IDX in } \\
2017 \text { 2018. The data used is secondary data and the } \\
\text { method used is panel data regression analysis with } \\
\text { the help of the Eviews } 10 \text { application to obtain a } \\
\text { comprehensive picture of the relationship between } \\
\text { variables with other variables. The sample in this } \\
\text { study consisted of 47 property \& real estate } \\
\text { msuryalam@gmail.com } \\
\text { companstina.kurniasih@mercubuanan.ac.id listed on the IDX in 2017 2018. the } \\
\text { results of this study are profitability and asset } \\
\text { structure has a significant influence on capital } \\
\text { structure. liquidity, growth and size have no } \\
\text { influence on capital structure. The results of the } \\
\text { simultaneous regression analysis state that the } \\
\text { profitability of the asset liquidity growth structure } \\
\text { and size affect the capital structure. } \\
\text { Keywords: Profitability, asset structure, liquidity, } \\
\text { growth, size, capital structure, property \& real estate }\end{array}$ \\
\hline
\end{tabular}

\section{INTRODUCTION}

A business in a company can run well if its financial manager properly uses funding resources both from its own capital and loan from outside parties. The function of a financial manager is to make buying decision that must be executed in order to obtain capital in the most efficient and effective way.

Funding decision that is executed properly will affect the company's value. The funding decision also determines how the company can face strict competition. Proper capital structure has positive impact on the continuity of a company since capital structure can influence the company's value.

From year to year, the number of humans born is getting bigger and it means that more people need houses for their residence. Property industry is one of industries registered in IDX. In 2018, the DER level was 1.6 and it means that funding from loan is bigger than funding from other resources.

The Table 1 shows that in 2016 the leverage of property industry was in unsolvable condition, since the total debt was bigger than the capital. In 2017, the use of debt decreased so that the condition is solvable. However, in 2018 , the level of debt increased significantly so that the ratio became 1.6. The high level of debt can be a problem if the company is unable to 
fulfil its obligation so that there is financial distress that can end with the company's bankruptcy.

Table 1. Capital Structure of Property and Real Estate Companies

\begin{tabular}{llll}
\hline Capital/Year & 2016 & 2017 & 2018 \\
\hline Total Debt & $188,079,848,745$ & $185,097,553,27$ & $428,219,829,25$ \\
Capital & $185,097,553,27$ & $228,242,960,21$ & $262,661,906,17$ \\
\hline Ratio & 1.016 & 0.915 & 1.6
\end{tabular}

Source: Indonesia Stock Exchange 2016-2018 (processed data)

Previous researches have been conducted to find the factors that influence company's capital structure.

The researchers used profitability variable since there was difference in the previous researches. Zhao and Ruiyang (2012) states that profitability does not have significant influence on capital structure. Meanwhile, a research conducted by Acaravci (2015) states that profitability influences capital structure. The researchers used liquidity variable because a research conducted by Prasasti (2018) states that liquidity has significant positive influence on capital structure. Meanwhile, a research conducted by Wahab and Khairudin (2012) says that liquidity does not influence capital structure. The researchers also used size variable since there was difference in the previous researches. The research conducted by Ayu and Putu (2017) says that size has significant influence on capital structure. Meanwhile, a research conducted by Mandagi, Sariguna and Lina (2015) says that size does not influence capital structure. And then, the researchers also used variable of asset structure since there was difference in the previous researches. The research conducted by Mandagi, Sariguna and Lina (2015) states that asset structure has significant negative influence on capital structure. And then, a research conducted by Dara and Mariah (2018) states that asset structure has no influence.

This research was aimed to find empirical proof of the influence of profitability, asset structure, company's growth and size on capital structure on property and real estate companies registered in Indonesia Stock Exchange in 2017-2018. This research is expected to be useful for investor candidates, company managers, and academicians.

\section{LITERATURE REVIEW}

According to Syamsuddin (2009), capital is property owned by a company which is used as foundation to establish and run such company. Capital can be from the company's internal and external sources.

According to Cahyo and Nur (2014), capital structure is the balance between foreign capital (long term) and proprietary capital. Capital structure issue is important issue for each company, since the condition of capital structure will have direct effect on financial position of such company. The company which has bad capital structure, where it has large amount of debt, will have heavy burden.

\subsection{Pecking Order Theory}

The Pecking Order theory was invented by Myers and Majluf (1984). They explained that Pecking Order Theory is a level of company's funding that shows that the company prefers internal fund in funding investment and implements it as growth opportunity. The Pecking Order theory says that managers prefer internal funding to external funding. 
Profitability. According to Kashmir (2014), profitability ratio is the ratio to assess the company's ability in seeking profit. This ratio also gives level of management effectiveness of a company. The management effectiveness is seen from profit generated from sales and investment revenue. The profitability ratio can be used by using comparison among various components in balance sheet and profit or loss report. This research used ROE (Return On Equity) measure, that is net profit after tax/total equity. The bigger company's profit, the bigger retained profit that can be used in the company's operation. The company's main choice in selecting funding is retained profit so that increasing capital structure will cause lower use of debt (Farisa \& Widati, 2017). The previous research conducted by Wahab and Khairuddin (2012) states that profitability has significant positive influence on capital structure. And then, a research conducted by Dewi and Gede (2017) also states that profitability has significant positive influence on capital structure.

Company Size. According to Susanti and Agustin (2015), company size can be construed as benchmark of company size seen from equity value, sales value, or company's total assets. According to Ariyanto (2002), company size will influence capital structure, the bigger company size, the bigger fund needed by company to invest. A research conducted by Zhao (2012) states that Size Variable has significant positive influence on capital structure. A research conducted by Hardanti and Barbara (2010) also says that Size has significant influence on capital structure.

H1: company size has positive influence on capital structure

Asset Structure. According to Brigham and Houston (2013) Asset Structure is the balance or comparison between fixed Asset and total assets. Asset structure depicts assets owned by company that later can be collateral or guarantee to get funding outside company. A company whose assets are adequate to be used as collateral tends to use much debt. Meanwhile according to Zuliani and Ayik (2014), "Asset structure in a company has influence on funding sources." A previous research conducted by Mandana and Luh (2015) says that asset structure has positive influence on capital structure.

H1: company's asset structure has positive influence on capital structure

Liquidity. According to Syahyunan (2015), liquidity ratio is a ratio which is used to know a company's ability in fulfilling its short-term obligation punctually. A company's liquidity is shown by the amount of current asset, that is asset which can be easily converted to cash that includes cash, securities, receivables, and supplies. If a company has high liquidity, it means that such company is capable of paying short-term debt. Therefore, the company tends to lower the total debts, that finally the capital structure will be smaller (Armelia \& Ruzikna, 2016). A research conducted by Suherman and Umi (2019) states that liquidity has positive influence on capital structure.

H1: Liquidity has positive influence on capital structure.

Company Growth. Kusumajaya (2011) thinks that growth is the increase or decrease of total assets owned by a company. A company's asset is asset used for company's operating activities. Such asset is expected to increase the company's operation result so that trust will increase and to give positive signal for external party or internal party in the company. The higher company's growth level will affect the company's capital structure, where such company tends to retain the use of debt to avoid risk due to business uncertainty (Brigham and Houston, 2013). The previous research conducted by Suweta and Made (2016) states that growth has significant positive influence on capital structure: 
H1: Growth has positive influence on capital structure.

\section{RESEARCH METHODS}

This research is a quantitative research with causality design, since it is aimed to find the influence of independent variables on dependent variable. The dependent variable is capital structure meanwhile the independent variables are profitability, asset structure, liquidity and company size.

The research population is property \& real estate companies registered in the Indonesia Stock Exchange. In 2018, there were 54 property \& real estate companies registered in the Indonesia Stock Exchange. The research sample was determined by nonprobability sampling technique. It is a sampling technique that does not give same probability for each population element to become sample (Sugiyono, 2012). The criteria in sampling of this research are: 1) the sample is property and real estate company which is continuously registered in the Indonesia Stock Exchange in 2017-2018 and 2) the company's financial report of 2017-2018 is completely available pursuant to the need of this research in the observation period. Based on such criteria, 47 companies became the research sample.

The research data is secondary data obtained from documentation. The data is crosssection data (47 companies) and time series data (year 2017-2018) or panel data.

The dependent variable (Capital Structure) was measured by Debt to Equity Ratio (DER). The independent variables are profitability (measured by Return on Equity, that is ratio of net profit after tax to Total Equity), asset structure (measured from the ratio of fixed asset to total assets), liquidity (measured by Current Ratio that shows the ratio of current assets to current liabilities), growth (which is measured by growth level, that is ratio of total assets $(\mathrm{t})$ - total assets $(\mathrm{t}-1)$ to total assets ( $\mathrm{t}-1)$ ) and company size which is measured with Ln (total assets).

To determine the influence of independent variables on dependent variable, the researchers used regression approach, that is double data panel regression. The regression model which was used is:

$\mathrm{SM}=\alpha+\beta 1$ ROEit $+\beta 2$ SAit $+\beta$ LIKit $+\beta 4$ GROit $+\beta$ SSIZEit $+\varepsilon$ it (1)

Where

$\mathrm{SM} \quad=$ Capital Structure

$\alpha \quad=$ Constant (intercept)

$\beta 1, \beta 2, \beta 3, \beta 4, \beta 5=$ Regression coefficient of each independent variable

$\mathrm{ROE} \quad=$ profitability

SA $\quad=$ Asset Structure

LIK $\quad=$ Liquidity

GRO = Growth

SIZE $\quad=$ company size

$\varepsilon \quad=$ Errorfterm

i company

$\mathrm{t} \quad=$ time period

The steps taken to analyze panel data regression are: 1) Choosing the best panel model among common effect model, fixed effect model, and random effect model. The determination of the best model used chow test, hausman test and lagrange multiplier test, 2) Conducting classic assumption test (normality test, autocorrelation test, multicollinearity test, and heteroscedasticity test). Classic assumption test was used to 
ensure that the generated regression model is BLUE (best linear unbiased estimator), 3) Analyzing the proposed regression model based on $\mathrm{F}$ test and determination coefficient score, and 4) Analyzing the influence of independent variables on dependent variable using $t$ test on the generated regression coefficient.

\section{RESEARCH RESULT AND DISCUSSION}

Table 2. Descriptive Analysis

\begin{tabular}{|c|c|c|c|c|c|c|}
\hline Capital & re Profit & ty Asset : & ure Liqu & Growth & Size & \\
\hline Mean & 0.4204 & 0.0591 & 0.0855 & 3.5054 & 0.0971 & $9.64 \mathrm{E}+12$ \\
\hline Median & 0.2530 & 0.0448 & 0.0320 & 2.0068 & 0.0472 & $5.83 \mathrm{E}+12$ \\
\hline Maximum & 2.8659 & 0.4420 & 0.6161 & 35.180 & 1.1749 & $5.21 E+13$ \\
\hline Minimum & 0.0010 & -0.2445 & 0.0002 & 0.0021 & -0.9098 & $7.51 \mathrm{E}+10$ \\
\hline
\end{tabular}

The Table 2 shows that capital structure (DER) has mean score of 0.4204 . It means that in every one hundred Rupiah of equity, there are 42.04 Rupiah of debt. In average, property and real estate companies in 2017-2018 are in solvable condition. The minimum DER score of 0.001 occurred in the company Sitara Propertindo in 2018. The maximum score of 2.8659 occurred in the company Plaza Indonesia Realty in 2017.

Profitability (ROE) has mean score of 0.0592. It means that one hundred Rupiah of equity generated net profit of 5.92 Rupiah. The maximum score of 0.4420 was in PT Natura City, Tbk of year 2017 and the minimum score -0.244500 occurred in PT Cowell Development, Tbk of year 2018.

Asset Structure has mean score of 0.8558. It can be explained that in average, every one hundred Rupiah of total assets has 85.58 Rupiah of fixed asset. The maximum score of asset structure of 0.6161 was in PT Duta Anggada Realty, Tbk of year 2017. The minimum score of 0.0002 occurred in PT Eureka Prima Jakarta, Tbk, also in 2017.

The mean score of Liquidity is 3.5055. It means that in average, property and real estate companies were in liquid condition. In every one hundred Rupiah of current liabilities, there were 350.5 Rupiah of current asset to fulfil them. The maximum score of 35.1803 occurred in PT Eureka Prima Jakarta, Tbk of year 2018. The minimum score of 0.0021 was in PT PP Properti of year 2017.

In average, property and real estate companies experienced growth of $9.7167 \%$. The maximum growth of $117.49 \%$ occurred in PT Lippo Cikarang, Tbk in 2017. The minimum growth of $-90.98 \%$ occurred in PT Sitara Propertindo, Tbk in 2018.

The size of property and real estate companies in general is $9.64 \mathrm{E}+12$ (Write in million Rupiah unit). The largest company was PT Bumi Serpong Damai in 2018, with asset value of 5.21E+13. The smallest company was PT Jababeka in 2018, with asset value of 7.51E+10 Rupiah. 


\section{Inferential Analysis}

The result test of the best panel regression model is presented on Table 3 . The best panel model is Random Effect Model (REM).

\begin{tabular}{llllll}
\hline Test & Option & Test & Stat_count & Prob & Conclusion \\
\hline Chow & CEM vs FEM & F & $\ldots \ldots$ & 0,000 & Not best PLS \\
Hausman & REM vs FEM & Chi2 & 8,92 & 0,780 & best REM \\
LM & REM vs CEM & $\begin{array}{l}\text { Breusch- } \\
\text { Pagan Cross- } \\
\text { section }\end{array}$ & & 0,000 & best REM \\
& & & & \\
\hline
\end{tabular}

\section{Classic Assumption Test}

\section{Normality Test}

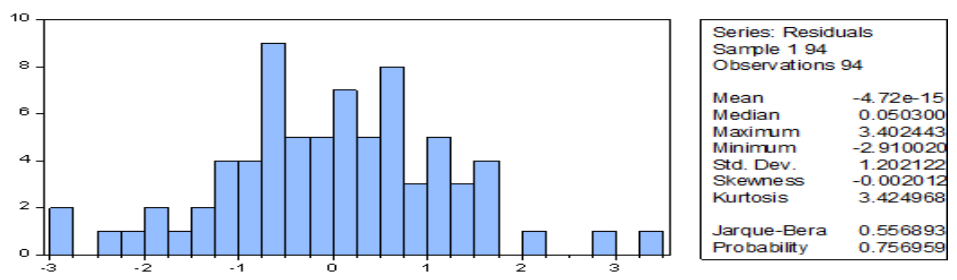

The result of normality test shows probability score of Jarque-Biera of 0.756959 . The probability score is bigger than significant degree $(\alpha=5 \%)$ and it means it accepts the H0. It can be concluded that its residual is normally distributed.

\section{Multicollinearity Test}

\begin{tabular}{cccc}
\hline Variable & $\begin{array}{c}\text { Coefficient } \\
\text { Variance }\end{array}$ & $\begin{array}{c}\text { Uncentered } \\
\text { VF }\end{array}$ & $\begin{array}{c}\text { Centered } \\
\text { MF }\end{array}$ \\
\hline C & 8.482 .832 & 4.046 .331 & NA \\
X1 & 6.049 .327 & 1.481 .105 & 1.075 .756 \\
X2 & 1.075 .246 & 1.568 .509 & 1.074 .336 \\
X3 & -1.006979 & 1.909 .896 & 1.094 .587 \\
X4 & -1.390176 & 1.245 .616 & 1.066 .779 \\
X5 & -1.009993 & 4.063 .735 & 1.122 .585 \\
\hline
\end{tabular}

The above multicollinearity test shows that VIF of each independent variable has score less than 10.00. It can be concluded that the model did not face multicollinearity issue.

\section{Heteroscedasticity Test}

\begin{tabular}{crrrr} 
Variable & Coefficient & Std. Error & t-Statistic & Prob. \\
\hline \hline C & & & & \\
Profitability & -0.9764 .288 & 7528.415 & 0.741761 & 0.4602 \\
Asset Structure & 0.399575 & 0.643529 & -1.517344 & 0.1328 \\
Liquidity & -0.011707 & 0.007155 & -1.636083 & 0.1054 \\
Growth & -0.218780 & 0.157786 & -1.386559 & 0.1691 \\
Size & -0.005961 & 0.025797 & -0.231095 & 0.8178
\end{tabular}

Source: Eviews Output 
The result of Heteroscedasticity test above shows that the score of Probability of Glejser test of each independent variable is bigger than 0.05 (5\%). Profitability variable (X1) has score of 0.132, Asset Structure (X2) scored 0.141, Liquidity (X3) scored 0.105, Growth scored 0.169 and Size (X5) scored 0.817. It can be concluded that there was no heteroscedasticity indication in this research model.

\section{Autocorrelation Test}

The autocorrelation test generated Durbin Watson score of 1.95. The DW table with significance of 0.05 and data number $(\mathrm{n})=94$ as well as $\mathrm{k}=5$ ( $\mathrm{k}$ is the number of independent variable) shows $\mathrm{dU}$ score of 1.77 . The $\mathrm{DW}$ score fulfils equation $\mathrm{du}<\mathrm{DW}<4-\mathrm{dU}$. It can be concluded that there was no autocorrelation issue.

The data processing using Eviews software generated data as presented on Table 5.

Table 5. The Influence of Profitability, Liquidity, Growth and Company Size on Capital Structure of Property and Real Estate Companies Registered in the IDX in 2017-2018 (Random Effect Model)

\begin{tabular}{llll}
\hline Variable & Regression Coef. & $\mathrm{t}_{\text {statistic }}$ & Prob \\
\hline Constant & 0.166479 & 0.215081 & 0.8302 \\
ROE & -0.063452 & 1.747924 & 0.0348 \\
SA & 0.798254 & 2.073441 & 0.0411 \\
LIK & -0.013646 & -1.281547 & 0.2034 \\
GRO & 0.041892 & 0.499484 & 0.6187 \\
Size & 0.008011 & 0.304325 & 0.7616 \\
& & & \\
\hline $\mathrm{R}^{2}$ & 0.072032 & & \\
Adj- $\mathrm{R}^{2}$ & 0.149307 & &
\end{tabular}

Based on the output of Eviews, the score of F-count is 2.7595 meanwhile the score of table $f$ with level of $\alpha=5 \%$ is 2.318 . Thus, $F$ count $>F$ table $(2.7595>2.318)$. Therefore, the $\mathrm{H} 1$ is accepted. It means that variables of profitability, asset structure, liquidity, growth and size simultaneously have significant influence on capital structure. Based on the above table, the score of Adjusted R squared is 0.1493017 and it can be concluded that independent variables used can explain in the amount of $14.93 \%$ on the dependent variable. The generated regression equation is:

$\mathrm{SM}=0.1664-0.06634 \mathrm{ROE}+0.7982 \mathrm{SA}-0.0136 \mathrm{LIK}+0.0418 \mathrm{GROit}+0.0080 \mathrm{SIZEit}$

The constant value is 0.166 with significance of 0.8302 . It means that the constant is not significant (does not have correlation).

The ROE regression coefficient has score of -0.0634 with the score of $t_{\text {count }}$ of 1.7479 ( $t_{\text {table }}$ of 1.662). It means that profitability has positive and significant influence on the capital structure of property and real estate companies. The coefficient score of 1.75 shows that if profit (ROE) increases by 1 unit, then the level of debt will increase by 1.75 unit.

The regression coefficient of Asset Structure has score of 0.7982 with $t_{\text {count }}$ of 2.073. The $t_{\text {count }}$ score is bigger than the $t_{\text {table }}$ score $(2.073>1.661)$. It means that asset structure has positive and significant influence capital structure. The coefficient score of 2.073 shows that 
if asset structure increases by 1 unit (total fixed assets to total assets), then the level of debt will increase by 2.07 unit.

The regression coefficient of liquidity has score of -0.0136 with $t_{\text {count }}$ of -1.281 . This score is smaller than the score of $t_{\text {table }}(-1.2815<1.661)$. It means that Liquidity has no influence on capital structure.

The regression coefficient of the fourth variable, growth, has score of 0.0418 . The score of $t_{\text {count }}$ of 0.499 is smaller than the score of $t_{\text {table }}(0.499<1.661)$. It means that growth has no significant influence on capital structure.

The regression coefficient of company size has score of 0.008 with $t_{\text {count }}$ of 0.304 . The $\mathrm{t}_{\text {count }}$ is smaller than $\mathrm{t}_{\text {table }}(0.3043<1.661)$. It means that Size has no significant influence on capital structure.

Among the variables with significant influence, the variable of Asset Structure has bigger influence.

The finding of this research that Profitability has positive and significant influence supports the trade-off theory. This finding also supports the result of Wahab's research (2012) that says that profitability of property companies has positive and significant influence on capital structure.

The finding of this research that asset structure has positive and significant influence supports the trade-off theory. This finding also supports the result of Nhung and Nguyen's research in 2017 that says that asset structure of property companies has positive and significant influence on capital structure.

The finding of this research that Size has no significant influence on capital structure does not support the trade-off theory. This finding is also in line with the result of Zhao's research (2012) that says that Size of property companies has no influence on capital structure.

\section{CONCLUSION}

The result of regression analysis test of panel data shows that profitability and Asset Structure have positive and significant influence on capital structure. Meanwhile Liquidity, Growth and Size have no influence on capital structure.

It was found that Asset structure has significant influence on capital structure. Therefore, if a company desires to increase its debt, then its fund should be invested in the form of fixed assets.

Investor who considers capital structure of a company in its investment policy will understand if property and real estate company increases its debt when its profitability and asset structure increase. Investors, especially majority investors, should also supervise the utilization of a company's debt so that it will be wise and the company remains capable of fulfilling is obligation.

The ability to explain regression model in this research is relatively low. Therefore, in the next researches, they shall include explaining variables, such as investment policy, dividend policy, or company's operation policy, as well as shares ownership by management or institution.

\section{REFERENCES}


Acaravci, Songul Kakkili (2015) "The Determinants of Capital Structure:Evidence from the Turkish Manufacturing Sector”. International Journal of Economics and Financial Issues Vol. 5, No. 1, 2015, pp.158-171

Armelia, S., \& Ruzikna. (2016). Pengaruh Ukuran Perusahaan, Profitabilitas, Likuiditas dan Struktur Aktiva terhadap Struktur Modal Perusahaan Manufaktur Go Publik. JOM FISIP, 3(2), 1-15.

Ariyanto, T. (2002). Pengaruh Struktur Kepemilikan Terhadap Struktur Modal Perusahaan. Jurnal Manajemen Indonesia. Vol.1, No.1, 64-71.

Ayu, Ni Komang dan Putu, Ni luh . 2017. Faktor - faktor yang mempengaruhi struktur modal perusahaan property \& real estate yang terdaftar di bei. E-Jurnal Manajemen Unud, Vol. 6, No. 6, p. 3168 - 3195

Brigham dan Houston. (2013). Dasar-Dasar Manajemen Keuangan. Jakarta:Salemba Empat

Cahyo, Hendri dan Nur, 2014. Pengaruh Profitabilitas, StabilitaPenjualan, Firm Size,Likuiditas DanStrukturAset Terhadap Struktur Modal Perusahaan Manufaktur Periode2010-2012. Jurnal Bisnis dan Akuntansi, Vol 14, No 4.

Dara, Siti Ruhana dan Mariah Mariah (2018). Faktor-faktor yang mempengaruhi struktur modal pada perusahaan subsektor property dan real estate yang terdaftar di bursa efek indonesia. Jurnal Riset Manajemen dan Bisnis (JRMB) Fakultas Ekonomi UNIATVol.3, No.3,Oktober 2018: 423 - 43024

Dewi, Ayu Intan \& Gede Mertha Sudiartha. (2017). pengaruh profitabilitas, ukuran perusahaan, dan pertumbuhan aset terhadap struktur modal dan nilai perusahaan EJurnal Manajemen Unud, Vol. 6, No. 4, 2017: 2222-2252

Farisa, N. A., \& Widati, L. W. (2017). Analisa Profitabilitas, Likuiditas, Pertumbuhan Penjualan, Struktur Aktiva Dan Kebijakan Dividen Terhadap Struktur Modal. In Prosiding Seminar Nasional Multi Disiplin Ilmu \& Call For Papers UNISBANK Ke-3 (SENDI_U 3) 2017 (pp. 640-649).

Hardanti, Siti \& Barbara Gunawan. (2010). pengaruh size, likuiditas, profitabilitas, risiko, dan pertumbuhan penjualan terhadap struktur modal (studi empiris pada perusahaan manufaktur di bursa efek indonesia). Jurnal Akuntansi dan Investasi Vol. 11 No. 2, halaman: 148-165

Kashmir. 2014. Analisis Laporan Keuangan. Jakarta: Rajawali pers

Kusumajaya, Oka. 2011. Pengaruh Struktur Modal dan Pertumbuhan Perusahaan terhadap Profitabilitas dan Nilai Perusahaan pada Perusahaan Manufaktur di BEI. Tesis Program Studi Magister Manajemen, Program Pascasarjana Universitas Udayana.

Myers, S. C., dan N. S. Majluf. (1984). Corporate Financing and Investment Decision When Firm Have Information That Investor do not Have. Journal of Financial Economic, Vol. 13 (2): 187-221.

Mandagi, Yuli Gretha, Posma Sariguna dan Santi Lina (2015). faktor-faktor yang mempengaruhi struktur modal pada perusahaan real estate dan properti di bursa efek indonesia periode 2009-2012. Jurnal Ilmiah Buletin Ekonomi Buletin Ekonomi ISSN: 1410-3842 Volume 19 No.1 Februari 2015

Mandana, Wayan Martha dan Luh Gede Artini. (2015). pengaruh struktur aktiva, tingkat pertumbuhan penjualan, profitabilitas dan pertumbuhan perusahaan terhadap struktur modal pada pt. pln (persero) distribusi bali periode 2004-2011. E-Jurnal Manajemen, [S.1.], v. 4, n. 7, july 2015. ISSN 2302-8912.

Najmudin. 2011. Manajemen Keuangan dan Aktualisasi Syar'iyyah Modern. Yogyakarta:CV. Andi.

Prasasti, Nikita Hayu. 2018. Analisis faktor-faktor yang mempengaruhi struktur modal perusahaan (skripsi). Yogyakarta (ID): Universitas Islam Indonesia. 
Sugiyono. 2012. Metode Penelitian Kuantitatif, Kualitatif dan R\&D. Bandung: Afabeta

Suherman, Resy Purnamasari dan Umi Mardiyati. 2019. Pengaruh Struktur Aset, Likuiditas, dan Profitabilitas Terhadap Struktur Modal Dimoderasi oleh Ukuraan Jurnal Ilmiah Manajemen, Volume 9, No. 2, Juni 2019.

Susanti, Yayuk dan Agustin, Sasi. 2015. Faktor Faktor yang Mempengaruhi Struktur Modal Perusahaan Food And Beverages. Jurnal Ilmu dan Reset Manajemen, Vol 4, No 9.

Suweta, Ni Made dan Made Rusmala Dewi. 2016. pengaruh pertumbuhan penjualan, struktur aktiva, dan pertumbuhan aktiva terhadap struktur modal E-Jurnal Manajemen Unud, Vol. 5, No.8, 2016:5172-5199

Syahyunan. (2015). Manajemen Keuangan (Kedua ed.). Medan: USU Press.

Syamsuddin, 2009. Manajemen Keuangan Perusahaan. Jakarta: Raja Grafindo Indonesia.

Wahab, Rabiah Abdul dan Khairudin Yusop (2012). Determinants of Capital Structure of Malaysian Property Developers. Middle-East Journal of Scientific Research 11 (8): 1013-1021, 2012

Zhao, Dan dan Ruiyang Chai (2012). "Capital Structure of Real Estate Firms in Chinese Stock Market”. International Journal of Management Sciences and Business Research Volume 1, Issue 9 2012- ISSN (2226-8235)

Zuliani, Selly dan Asyik, Nur Fadjrik. 2014. Pengaruh Profitabilitas, Pertumbuhan Penjualan, Struktur Aset dan Tingkat Pertumbuhan Terhadap Struktur Modal. Jurnal Ilmu dan Riset Akuntansi. Vol 3 No 7. 